GENE 03545

\title{
A novel phosphate-regulated expression vector in Escherichia coli
}

(Prokaryotic expression vector; recombinant DNA; ugp promoter; pho regulon; phosphate regulation)

\author{
Ti-Zhi Su", Herbert Schweizer ${ }^{b}$ and Dale L. Oxender" \\ a Department of Biological Chemistry, University of Michigan, Ann Arbor, MI 48109-0606 (U.S.A.) and ${ }^{b}$ Department of Microbiology. University \\ of Calgary, Calgary, Alberta (Canada T2N 4NI)
}

Received by D.I. Friedman: 16 November 1989

Revised: 11 January 1990

Accepted: 18 January 1990

\section{SUMMARY}

The ugp promoter $\left(p_{\text {ugp }}\right)$ responsible for expression of the binding-protein-dependent sn-glycerol-3-phosphate transport system in Escherichia coli was cloned into a small multicopy plasmid pTER5, a derivative of pBR322, between the transcription terminators rpoCt and $t_{\mathrm{L1}}$. The resulting expression vector, pPH3, permits convenient insertion of structural genes containing their own translational-initiation regions, into the multiple-cloning site derived from the pUC19 plasmid. The efficiency and regulatory properties of $p_{\text {ugp }}$ were measured using $x y l E$ and lac $Z$ as reporter genes, which code for the corresponding enzymes catechol-2,3-dioxygenase (C230) and $\beta$-galactosidase ( $\beta \mathrm{Gal})$, respectively. Enzyme activities were virtually completely repressed in the presence of excess inorganic phosphates $\left(P_{i}\right)$ and high concentrations of glucose. Maximal induction was observed at limiting $P_{i}(<0.1 \mathrm{mM})$ and normal levels of glucose $(0.2-0.4 \%)$. The maximum expression of the $p_{\text {ugp }}$-directed $\beta \mathrm{Gal}$ synthesis was approx. $80 \%$ of that directed by strong $p_{\text {rac }}$. When the $x y l E$ gene was maximally expressed, the induced enzyme constituted approx. $50 \%$ of total cellular protein as judged by laser densitometry following sodium dodecyl sulfate-polyacrylamide-gel electrophoresis. These results suggest the usefulness of the $p_{\text {ugp }}$ in expression vectors for strong, but controlled, expression of cloned genes in $E$. coli. This $\mathrm{P}_{\mathbf{i}}$ controlled vector can be adapted to large-scale fermentation by using $\mathbf{P}_{1}$-limiting growth conditions.

\section{INTRODUCTION}

Promoter strength and its controllability are two important criteria in the construction of a good expression system. The controllable expression can often be achieved by manipulating the level of regulatory factors, such as specific repressors, co-repressors or inducers (Pouwels et al., 1985).

Correspondence to: Dr. D.L. Oxender, Department of Biological Chemistry, University of Michigan, Ann Arbor, MI 48109-0606 (U.S.A.) Tel. (313) 764-8197; Fax (313) 763-4581.

Abbreviations: $A_{600}$, absorbance at $600 \mathrm{~nm}$; Ap, ampicillin; $\beta \mathrm{Gal}$, $\beta$-galactosidase; bla, gene encoding Bla; Bla, $\beta$-lactamase; bp, base pair(s); CRP, cAMP receptor protein; C230, catechol 2,3-dioxygenase; $\Delta$, deletion; $E$., Escherichia; G3P, sn-glycerol-3-phosphate; IPTG, isopropyl- $\beta$-D-thiogalactopyranoside; kb, kilobase(s) or 1000 bp; MCS, multiple-cloning site; ori, origin of DNA replication; PAGE, polyacrylamide-
It can also be achieved by control of the copy number of the vector carrying the gene of interest (Pouwels et al., 1985) or by promoter inversion (Hasan and Szybalski, 1987). Many previously described expression systems require inducers such as IPTG which are expensive. For large-scale or repeat experiments such methods may become rather unattractive options. Therefore, it is desirable to have a vector in which

gel electrophoresis; $\mathbf{P}_{i}$, inorganic phosphate; Pollk, Klenow (large) fragment of $E$. coli DNA polymerase $I ; p_{\text {ret }}$, tet promoter; $p_{\text {usp }}$, ugp promoter; ${ }^{\mathbf{R}}$, resistance; RBS, ribosome-binding site; moCt, poC terminator; SDS, sodium dadecyl sulfate; sn, stereospecific numbering; tacp/o, tac promoter and operator; TG, Tris(hydroxymethyl)aminomethane and glucose (Echols et al., 1961); $t_{21}$, first terminator of the major leftward transcription in phage $\lambda ; t s p$, transcription start point(s); ugp, sn-glycerol-3phosphate uptake operon; $x y l E$, gene encoding $\mathrm{C} 23 \mathrm{O}$; [ ], designates plasmid-carrier state. 
gene expression can be controlled by the levels of nutrients such as $\mathbf{P}_{\mathrm{i}}$.

$P_{i}$ is an attractive nutrient for purposes of gene regulation for the following reasons: in $E$. coli, the response to $P_{i}$ starvation is rapid with maximum expression of the genes involved in this stress response achieved in as little as
30-60 min (Schweizer and Boos, 1985). In addition, several genes in the pho regulon, e.g. ugpB for the G3P binding protein, are expressed at high levels (Schweizer and Boos, 1984). The aim of this study was to develop a novel $p_{\text {ugp }}$-based expression system that is under $P_{i}$ control.

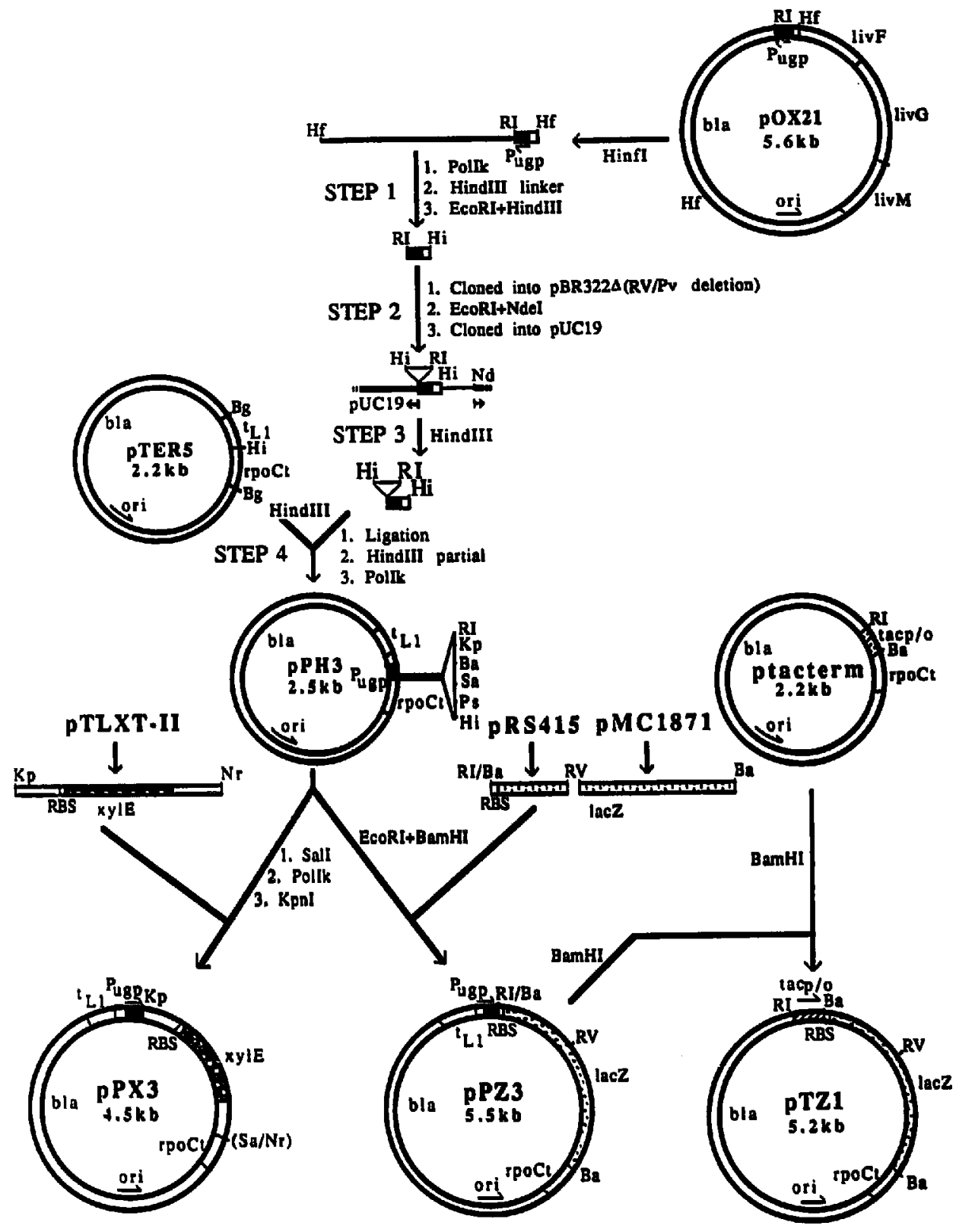

Fig. 1. Construction of plasmids pPH3, pPX3, pPZ3 and pTZ1. A 174-bp fragment from pOX21 (Penelope et al., 1985), which contains the $p_{\text {wep }}$ and its regulatory sequence flanked by $E c 0 R I$ and $H i n f I$, sites, was subcloned into plasmid pTER5 containing the transcription terminators, rpoCt and $t_{L}$, in four steps: (1) replacement of the blunt-ended Hinfl site with a HindIII site by ligating with synthetic HindIII linkers; (2) positioning of the EcoRI-HindIII fragment next to the EcoRI site of the MCS of pUC19; (3) isolation of the HindIII fragment, which contains the MSC and the $p_{\text {ugp }}$; and (4) insertion of the isolated fragment into the same site of pTER5, followed by elimination of the extra HindIII site upstream from the $p_{\text {usp }}$ by HindIII partial digestion and filling in the single-stranded ends. The resulting $p_{\text {uom }}$ expression vector is designated pPH3. To construct pPX3 the KpnI-Nrul fragment containing the $x y l E$ gene was isolated from the promoter probe plasmid pTLXT-11 (Tseng et al., 1988) and inserted into pPH3 treated in succession with SalI, Pollk and KpnI. To construct pPZ3 the EcoRI-EcoRV 5' lacZ fragment and the EcoRV-BamHI 3 'lacZ fragment were isolated from pRS415 and pMC1871, respectively (Simons et al., 1987; Casadaban et al., 1983), and ligated between the EcoRI and BamHI sites on pPH3 plasmid. The pTZ1 plasmid was obtained by inserting the BamHI fragment of the lacZ gene from pPZ3 plasmid into the vector ptacterm (Paluh and Yanofsky, 1986). Ba, BamHI; Bg, BgllI; Hf, Hinfl; Hi, HindIII; Kp, KpnI; Nd, NdeI; Ps, PstI; Pv, Pvull; RI, EcoRI; RV, EcoRV. (P = pusp). 


\section{EXPERIMENTAL AND DISCUSSION}

\section{(a) Construction of $p_{\text {ugp }}$ expression vector}

The construction of the $p_{\text {ugp }}$-based expression vector pPH3 (2.5 kb) is outlined in Fig. 1. This high-copy-number plasmid contains: (1) an $A p^{\mathrm{R}}$ marker; (2) two terminators, rpoCt and $t_{L I} ;(3)$ the MCS in between the two terminators; and (4) the $p_{\text {usp }}$ immediately upstream from the MCS. The nt sequence from the tsp before the MCS is: GCGAGCATAAAACGCGT.

\section{(b) Construction of promoter-reporter gene plasmids}

Three expression plasmids, pPX3, pPZ3 and pTZ1, were constructed as outlined in Fig. 1. The xylE gene for C23O was subcloned from pTLXT-11 (Tseng et al., 1988) into the MCS of the vector pPH3 (pPX3). The lac Z structural gene was subcloned from plasmids pRS415 (Simons et al., 1987) and pMC1871 (Casadaban et al., 1983) into vectors pPH3 and ptacterm (Paluh and Yanofsky, 1986), respectively (pPZ3 and pTZ1).

\section{(c) Regulated expression of the $p_{\text {agp }}-x y l E$ and $p_{\text {ugp }}-l a c Z$} genes

Our recent studies show that, in addition to the dominant pho regulation, the $p_{\text {ugp }}$ is also subject to cAMP-CRPmediated control (T.-Z.S. and D.L.O., in preparation). Under high concentrations of both $P_{i}$ and glucose more than $98 \%$ of expression directed by the $p_{\text {ugp }}$ could be repressed even after the cells were at steady state of growth for $6 \mathrm{~h}$ (Table I), and the basal level of $\beta \mathrm{Gal}$ activity from the $p_{\text {ugp }}$ was nearly the same as that from the repressed $p_{\text {rac }}$ (about $1.7 \%$ ). The $P_{i}$ concentration $(6.4 \mathrm{mM})$ as in Table $I$ is in much excess. To adapt this expression vector to

\section{TABLE I}

Effect of glucose on the pho-independent expression of $p_{\text {ugp }}-l a c Z$ and $P_{\text {ugp }}-x y l E$ genes

\begin{tabular}{lll}
\hline $\begin{array}{l}\text { Glucose } \\
(\%)\end{array}$ & $\begin{array}{l}\beta G_{a l}^{\mathrm{b}} \\
\left(\text { unit// } / A_{600}\right)\end{array}$ & $\begin{array}{l}\text { C230 } \\
\text { (unit// }\end{array}$ \\
\hline 0.2 & 5794 & 645 \\
0.5 & 782 & 103 \\
1.0 & 578 & 8 \\
2.0 & 485 & 2 \\
\hline
\end{tabular}

- Cells, JM109[pPZ3] ( $\left.\triangle 1 a c-p r o A B, l a c /{ }^{9}\right)$ and DH5aF' [pPX3], were grown overnight in TG medium supplemented with $6.4 \mathrm{mM} \mathrm{K}_{2} \mathrm{HPO}_{4}$ (high $\mathbf{P}_{i}$ ), harvested, washed twice with $P_{1}$ - and glucose-free medium, and then inoculated into the same high $P_{i}$ medium, but with various concentrations of glucose.

b The cells were harvested after $6 \mathrm{~h}$ at stationary phase and subjected to enzyme assays (Miller, 1972; Tseng et al., 1988). The specific activities shown here are expressed as nmol of products liberated/min in $A_{600}=1$ of lysed cells. large-scale synthesis the concentrations of $P_{i}$ and other nutrients, such as carbon, can be adjusted in such a way (e.g., 0.5-0.6 $\mathrm{mM}$ for $P_{i}$ ) that the $P_{i}$ becomes limiting when the desired cell mass is achieved. The cells will stop growing and the cloned gene will be expressed. For the purpose of the study reported here the induction of $p_{\text {ugsp }}$ was achieved by diluting $P_{i}$ to $0.1 \mathrm{mM}$ and glucose to $0.2-0.4 \%$. Under these conditions the specific activity of the enzymes expressed from the $p_{\text {ugp }}$ reached a maximum in approx. 6-8 h after exponential growth.

\section{(d) Relative strength of the $p_{\text {ugp }}$}

Using laser densitometry of the stained bands on the SDS-PAGE gels the induced $\mathrm{C} 23 \mathrm{O}$ from the $p_{\text {ugp }}$ in plasmid pPX 3 was shown to represent approx. $50 \%$ of the total cellular proteins (Fig. 2), a level which is much higher than that obtained from $p_{\text {set }}$ in plasmid pTS92 (Inouye et al., 1981). The relative strength of $p_{\text {usp }}$ was further tested by comparing enzyme activities expressed from the $p_{\text {ugp }}, p_{\text {ret }}$ and $p_{\text {rac }}$. The activity of Bla, encoded by bla gene on these

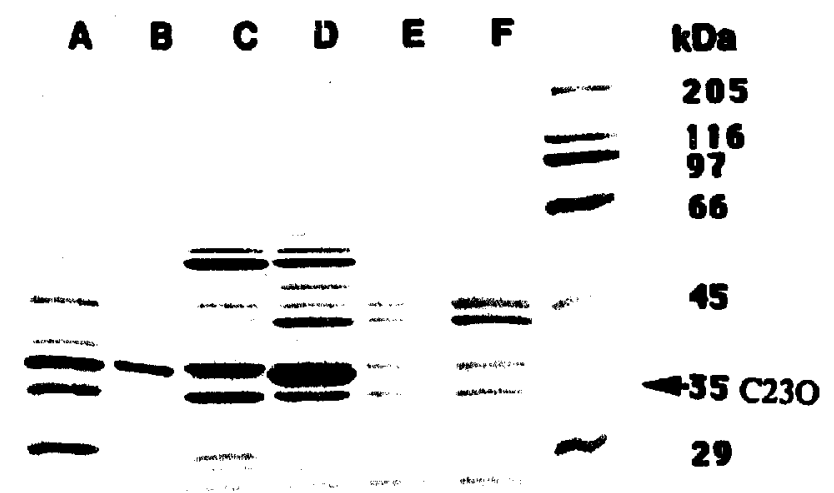

Fig. 2. Comparison of $P_{\text {tef }}$ (plasmid pTS92) and $P_{\text {ugp }}$ (plasmid pPX3). The overnight culture of $\mathrm{DH} 5 \alpha \mathrm{F}^{\prime}$ strain ( $(\mathrm{acc} 169$, recAl) harboring plasmids pTS92, pPX3 or pPH3 (control) was grown in TG medium (Echols et al, 1961) supplemented with $\mathrm{K}_{2} \mathrm{HPO}_{4}(1.0 \mathrm{mM})$, Ap $(50 \mu \mathrm{g} / \mathrm{ml})$ and aa $(20 \mu \mathrm{g} / \mathrm{ml}$ each). The cells were harvested, washed twice with $P_{i}$-free $T G$ medium, and then resuspended in 10 vols. of high $P_{i}$ or low $P_{i}$ TG medium and shaken at $37^{\circ} \mathrm{C}$. Samples from low $P_{i}$ medium (lanes $D$ and $F$ ) and high $P_{i}$ medium (lanes $A, C$ and $E$ ) were removed after overnight growth (about $8 \mathrm{~h}$ after exponential growth). The whole-cell lysates (corresponding to $A_{600}=0.25$ ) were electrophoresed through a $0.1 \%$ SDS-15\% PAGE and stained with Coomassie brilliant blue. The $\mathbf{C} 230$ was purified according to the procedure by Nozaki (1970). Protein standards (in $\mathrm{kDa}$ ) are shown on the right margin. Lanes: $A$, lysate from cells harboring the $p_{t e t}-x y l E$ plasmid $p T S 92 ; B$, purified C230; C-D, lysate from cells harboring $p_{\text {ugp }}-x y l E$ plasmid pPX3; E-F, lysate from cells containing the $p_{\text {ugp }}$ expression vector pPH3. 
TABLE I!

Relative strength of the $p_{\text {ugp }}$

\begin{tabular}{|c|c|c|c|c|c|c|c|}
\hline \multirow[t]{2}{*}{ Host ${ }^{\mathrm{a}}$} & \multirow[t]{2}{*}{ Plasmid/promoter } & \multirow{2}{*}{$\begin{array}{l}\beta \mathrm{Gal}^{\mathrm{b}} \\
\text { (A) }\end{array}$} & \multirow{2}{*}{$\begin{array}{l}\mathrm{C} 23 \mathrm{O}^{\mathrm{b}} \\
\text { (B) }\end{array}$} & \multirow{2}{*}{$\begin{array}{l}\text { Bla }^{b} \\
\text { (C) }\end{array}$} & \multirow{2}{*}{$\begin{array}{l}\text { Relative activity } \\
\text { (A or } B / C \text { ) }\end{array}$} & \multicolumn{2}{|c|}{ Relative promoter activity } \\
\hline & & & & & & Promoter & Ratio \\
\hline JM109 & $\mathrm{pTZ1} / p_{t a c}$ & 37878 & & 152 & 249 & & \\
\hline JM109 & $\mathrm{pPZ3/p_{ \text {uQP } }}$ & 28300 & & 143 & 198 & $P_{\text {tac }} / P_{\text {rugp }}$ & $1 / 0.80$ \\
\hline DHSaF' & $\mathrm{pPX} 3 / p_{\text {ugp }}$ & & 11600 & 152 & 76.3 & & \\
\hline DHSaF' & pTS92/put & & 3200 & 296 & 10.8 & $P_{\text {ugp }} / p_{\text {res }}$ & $7 / 1$ \\
\hline
\end{tabular}

a Cells were grown overnight and treated as described in Fig. 2. The washed cells were then diluted into 10 vols. TG medium with $0.064 \mathrm{mM} \mathrm{K}_{2} \mathrm{HPO}_{4}$ (low $\mathbf{P}_{\mathrm{i}}$ ). For JM109[pTZ1] strain, $1 \mathrm{mM}$ IPTG was added after the inoculation. Aliquots of cells were withdrawn every hour and immediately put on ice. Chloramphenicol was added to the samples to produce $100 \mu \mathrm{g} / \mathrm{ml}$ final concentration.

b The ice-cold cells $(0.5 \mathrm{ml})$ were pelleted, washed once, and resuspended in $0.1 \mathrm{M}$ Tris $\cdot \mathrm{HCl}(\mathrm{pH} 8.0)$ for $\beta \mathrm{Gal}$ and Bla assays or in $0.05 \mathrm{M} \mathrm{K} \mathrm{K}_{2} \mathrm{HPO}$, containing $10 \%$ acetone (pH 7.5) for C230 assays. For $\beta G$ al and C23O a differential rate of synthesis was determined, using the slope of the line (R $>0.99$ ) generated when enzyme activity is plotted against cell growth $\left(A_{600}\right)$. The unit of the differential rate was calculated as nmol of product liberated/min/ $A_{600}$ -

promoter-fusion plasmids, was also measured to correct for variable plasmid copy number. The data in Table II indicate that the $p_{\text {ugp }}$ appears to be $\mathbf{8 0} \%$ as efficient in promoting expression as the strong $p_{t a c}$ and about seven times stronger than the $p_{\text {Ieet }}$, suggesting that the $p_{u g p}$-based expression vector can also be used for high-level expression.

\section{(e) Conclusions and discussion}

(1) The gene to be expressed using the $p_{\text {ugp }}$-based expression vector pPH3 should contain RBS, however, if translation initiation sequences are inserted at the MCS by site-directed mutagenesis, the resulting vectors will be suitable for expression of genes without initiation signals.

(2) The expression directed by the $p_{M g p}$ was virtually completely repressed at excess $P_{i}(>1 \mathrm{mM})$ and high concentrations of glucose $(>1 \%)$. The induction appeared when cells were deprived of $P_{i}$. For a large-scale fermentor dilution to lower the $P_{1}$ level is impractical. As an alternative, the starting levels of $P_{i}$ and glucose in the growth medium can be adjusted, depending on the growth conditions, so that only the $P_{i}$ becomes limiting when cells reach a predetermined mass. The $P_{i}$-starved cells will now produce the desired protein. If the protein to be made is not toxic to the cells, continuous culture can also be an attractive approach to make large quantities of protein of interest by the pho-regulated expression system (Pages et al., 1987).

(3) The $\mathbf{C 2 3 0}$ expressed from the $p_{\text {ugp }}$ corresponded to $50 \%$ of the total cellular protein. Quite similar results were obtained utilizing $p_{\text {ugp }}-g l p K$ fusion (data not shown). The promoter strength and controllability of the $p_{\text {ugp }}$ is close to the strong $P_{\text {rac }}$.

(4) The $p_{\text {kEP }}$ is useful for expression of proteins possibly in all $E$. coli strains harboring a functional pho regulatory circuit (Wanner, 1987). The $p_{\text {ugpp }}$ can be used for expression of genes not only when the genes are integrated into a specialized expression vector such as pPH3, but also when integrated into more commonly used cloning vectors, such as pBR322 or pUC19 (data not shown). Therefore, the DNA fragments harboring the portable, $P_{i}$-repressible, $p_{\text {ugp }}$ may be of general use for expression of genes in already existing replicons.

\section{REFERENCES}

Casadaban, M.J., Martinez-Arias, A., Shapira, S.K. and Chou, J. $\boldsymbol{\beta}$-Galactosidase gene fusions for analyzing gene expression in Escherichia coll and yeast. Methods Enzymol. 100 (1983) 293-308.

Echols, H., Garen, A., Garen, S. and Torriani, A.-M.: Genetic control of repression of alkaline phosphate in E. coll. J. Mol. Biol. 3 (1961) 425-438.

Inouye, S., Nakazawa, A. and Nakazawa, T.: Molecular cloning of TOL genes $x y l B$ and $x y l E$ in Escherichla coll. J. Bacteriol. 145 (1981) 1137-1143.

Hasan, N. and Szybalski, W.: Control of cloned gene expression by promoter inversion in vivo: construction of improved vectors with a multiple cloning site and the prac promoter. Gene 56 (1987) 145-151.

Miller, J.H.: Experiments in Molecular Genetics. Cold Spring Harbor Laboratory, Cold Spring Harbor, NY, 1972, pp. 352-355.

Nozaki, M.: Metapyrocatechase (Pseudomonas). Methods Enzymol. 17 (1970) 522-525.

Pages, J.-M., Belaich, A., Anban, J. and Lazdunski, C.: Production and purification of human growth hormone-releasing factor from continuous cultures of recombinant-plasmid-containing Escherichia coli. Eur. J. Biochem. 168 (1987) 239-243.

Paluh, J.L. and Yanofsky, C.: High level production and rapid purification of the $E$. coli twp repressor. Nucleic Acids Res. 14 (1986) 7851-7860.

Penelope, M.N., Mayo, M.M., Su, T.Z, Anderson, J.J. and Oxender, D.L.: Identification of liv $G$, a membrane-associated component of the branched-chain amino acid transport in Escherichia coli. J. Bacteriol. 163 (1985) 1196-1202.

Pouwels, P.H., Enger-Valk, B.E. and Brammar, W.J.: Cloning Vuctors. A Laboratory Manual, Vol. IB. Elsevier, Amsterdam, 1985, pp. i-iv.

Schweizer, H. and Boos, W.: Characterization of the ugp region containing the genes for the phoB dependent sn-glycerol-3-phosphate transport system of Escherichia coli. Mol. Gen. Genet. 197 (1984) 161-168. 
Schweizer, H. and Boos, W.: Regulation of ugp, the sn-glycerol-3-phosphate transport system of Escherichia coli K-12 that is part of the pho regulon. J. Bacteriol. 163 (1985) 392-394.

Simons, R.W., Houman, F. and Kleckner, N.: Improved single and multicopy lac-based cloning vectors for protein and operon fusions. Gene 53 (1987) 85-96.

Tomizawa, J.: Control of ColE1 plasmid replication: initial interaction of RNA I and the primer transcript is reversible. Cell 40 (1985) 527-535.

Tseng, M.J., Hilfinger, J.M., Walsh, A. and Greenberg, G.R.: Total se- quence, flanking regions, and transcripts of bacteriophage T4 urds gene, coding for $\alpha$ chain of ribonucleotide diphosphate reductase. J. Biol. Chem. 263 (1988) 16242-16251.

Wanner, B.L.: Phosphate regulation of gene expression in Escherichia coli. In Neidhardt, F.C., Ingraham, J.L., Low, K.B., Magasanik, B., Schaechter, M. and Umbarger, H.E. (Eds.), Escherichia coli and Salmonella typhimurium. Cellular and Molecular Biology. American Society for Microbiology, Washington, DC, 1987, pp. 1326-1333. 